MediaTor, Vol 12 (2), Desember 2019, 199-211

\title{
Pengaruh Motif Selfie Terhadap Keterbukaan Diri Generasi Milenial
}

\author{
${ }^{1}$ Merlin, ${ }^{2}$ Dinda Rakhma Fitriani \\ Fakultas Ilmu Komunikasi Universitas Gunadarma, Jl. Margonda Raya No. 100, Depok 16424, Jawa Barat \\ E-mail: ${ }^{1}$ chiaamerlin@gmail.com, ${ }^{2}$ dinda_rf@gunadarma.ac.id
}

\begin{abstract}
Abstrak: Telepon pintar atau smartphone merupakan telepon genggam yang fungsi dan penggunaannya menyerupai komputer. Telepon pintar hadir dengan berbagai fitur canggih untuk menunjang aktifitas penggunanya. Salah satunya dengan kecanggihan kamera untuk menciptakan kualitas foto yang mengungguli alat fotografi. Berkembangnya teknologi kamera depan smartphone mendorong munculnya fenomena selfie dikalangan generasi milenial. Generasi milenial adalah generasi yang banyak dipengaruhi oleh smartphone, internet dan media sosial. Salah satu media sosial yang berfokus pada konten visual dengan teks sebagai pelengkap adalah Instagram. Penelitian ini bertujuan untuk mengetahui Pengaruh Selfie pada Instagram Terhadap Keterbukaan Diri Generasi Milenial. Teori yang digunakan dalam penelitian ini adalah Uses and Gratification Theory. Metode yang digunakan dalam penelitian ini adalah metode kuantitatif dengan paradigma positivistik, peneliti mengumpulkan data menggunakan kuesioner. Penelitian ini dilakukan pada generasi milenial dengan rentang usia 19-39 tahun. Sampel pada penelitian ini berjumlah 100 responden, dengan menggunakan teknik Cluster Sampling. Dari analisis korelasi antara variabel Motif Selfie pada Instagram dan variabel Keterbukaan Diri memiliki hubungan yang cukup kuat dan positif. Setelah dilakukan uji regresi dihasilkan persamaan $Y=12,009+1,027 X$ dengan hasil koefisien determinasi sebesar 52,1\%, yang menandakan bahwa keterbukaan diri generasi milenial dipengaruhi motif selfie pada Instagram, sedangkan sisanya disebabkan oleh faktor lain.
\end{abstract}

Kata kunci: selfie, instagram, keterbukaan diri, teori uses and gratification.

\begin{abstract}
Smartphones are mobile phones that can function like a computer with various advanced features to support the activities of users. One of them is the camera to create quality photos that outperform photographic tools. The development of smartphone front camera technology encourages the emergence of selfie phenomena among millennials. The millennial generation is the generation that is heavily influenced by smartphones, the internet, and social media. One of social media that focuses on visual content with text as a complement is Instagram. This study aims to determine the effect of Instagram selfie on Millennial Generation self openness. The theory used in this research is The Uses and Gratification Theory. The method used in this study is a quantitative method with a positivist paradigm and researchers collect the data using questionnaire. This research was conducted in millennials with an age range of 19-39 years. The sample in this study amounted to 100 respondents, using the Cluster Sampling technique. From the correlation analysis between Selfie Motive variables on Instagram and Self Disclosure variables have a fairly strong and positive relationship. After the regression test, the equation $Y=12,009+1,027 X$ was produced with the result of a coefficient of determination of $52.1 \%$, which indicates that the self-disclosure of the millennial generation is influenced by selfie motives on Instagram, while the rest is caused by other factors.
\end{abstract}

Keywords: selfie, instagram, self disclosure, uses and gratification theory.

DOI: https://doi.org/10.29313/mediator.v12i2.5037 


\section{PENDAHULUAN}

Perkembangan teknologi informasi dan komunikasi yang demikian pesat begitu dirasakan manfaatnya oleh masyarakat. Telepon pintar atau smartphone adalah salah satu produk dari perkembangan teknologi informasi yang membantu manusia terhubung satu sama lain tanpa mengenal ruang dan waktu. Kini telepon sudah berubah fungsi, tidak sekadar untuk berbicara namun untuk mengirim pesan, menjelajah internet, perbankan, dll. Kemampuannya yang sudah jauh melebihi generasi sebelumnya menjadikan smartphone sebagai kebutuhan sekaligus gaya hidup di masyarakat. Pertambahan fungsi teknologi akibat perkembangan zaman ini semakin memanjakan kehidupan manusia.

Smartphone atau telepon pintar merupakan telepon genggam yang mempunyai kemampuan fungsi dan penggunaan menyerupai komputer. Smartphone hadir dengan berbagai fitur canggih untuk menunjang aktifitas penggunanya. Salah satunya dengan kecanggihan kamera untuk menciptakan kualitas foto yang mengungguli alat fotografi. Jika dalam momen tertentu, dengan menggunakan smartphone akan jauh lebih mudah dan cepat untuk mengabadikannya. Oleh sebab itu, disebut sebagai kamera bidik zaman ini.

Selain kualitas kamera yang semakin baik, ketersediaan perangkat smartphone yang canggih juga berbanding lurus dengan penggunaan internet. Dilansir dari Asosiasi Penyelenggara Jasa Internet Indonesia (APJII) pada 2018, pengguna internet meningkat dari tahun sebelumnya 143,2 juta jiwa menjadi 171,17 juta jiwa. Pemanfaatan internet memegang kunci utama untuk saling terhubung satu sama lain. Kehadiran internet menjadi cikal bakal berkembangnya media sosial sebagai sarana bersosialisasi secara global. Media sosial berfungsi sebagai sarana informasi dan komunikasi sekaligus wadah mengekspresikan diri pengguna baik informasi yang bersifat umum maupun privacy. Keberadaan situs media sosial ini memunculkan keinginan penggunanya untuk mengungkapkan identitas diri atau menciptakan citra diri yang baik salah satunya dengan mengunggah foto dan update status.

Dilansir dari APJII pemanfaatan internet banyak digunakan untuk media sosial dengan jumlah 19,1\%. Salah satu media sosial yang sedang banyak digunakan oleh pengguna smartphone adalah Instagram. Instagram adalah salah satu jenis media sosial yang para penggunanya bisa mengunggah berbagai foto untuk diperlihatkan kepada pengguna lain. Dilansir dari kompas.com Instagram mengumumkan bahwa pengguna aktif di Indonesia tembus 1 miliar per Juni 2018. Pertumbuhannya paling signifikan yang mencapai 5 persen dari kuartal ke kuartal dibandingkan Facebook. Angka ini memposisikan Indonesia sebagai negara pengguna Instagram terbesar se-Asia Pasifik. Tujuan umum dari Instagram itu sendiri salah satunya yakni sebagai sarana kegemaran dari masing-masing individu yang ingin mempublikasikan kegiatan, barang, tempat atau pun dirinya sendiri kedalam bentuk foto.

Instagram merupakan aplikasi yang relevan untuk penelitian ini karena merupakan media sosial yang berfokus pada konten visual dengan teks sebagai pelengkap. Berbeda dengan jenis media sosial lain seperti Facebook dan Twitter, yang menjadikan teks sebagai konten utama. Banyaknya fitur yang disediakan oleh Instagram membuat penggunanya mengakses fitur tersebut dengan berbagai tujuan salah satunya ajang aktualisasi diri atau secara tidak langsung melakukan self disclosure (keterbukaan diri) melalui foto selfie. Selfie adalah kegiatan mengabadikan foto yang diambil sendiri, 
biasanya menggunakan smartphone atau webcam dan diunggah melalui situs media sosial (Oxford Dictionaries word of the year 2013). Pada tanggal 28 Agustus 2013 secara resmi kata selfie dimasukkan ke dalam kamus Oxford Dictionaries, kata selfie mengalami peningkatan dalam penggunaannya sebesar $17.000 \%$ dari tahun sebelumnya. Karena itu Oxford Dictionaries menobatkan kata selfie sebagai Word of the year 2013.

Selfie erat kaitannya dengan self disclosure (keterbukaan diri). Dimana individu berupaya untuk mengkontruksi dirinya dalam konteks online melalui foto (Valerie Barker, 2019:3). Selain itu, selfie merupakan bentuk komunikasi secara non-verbal yaitu penyampaian pesan dilakukan menggunakan ekspresi dalam foto. Selfie dianggap sebagai perangkat citra diri dalam masyarakat. Selfie dalam media sosial berpengaruh dalam penilaian diri yakni ketika sebagian orang memberi penilaian terhadap dirinya berdasarkan jumlah like yang mereka terima. Pada era digital ini, selfie telah menjadi cara berkomunikasi yang diterima masyarakat. Selfie merupakan cara modern memamerkan diri karena semakin banyak dari kita yang berkomunikasi secara online, demikianlah cara dan tempat kita memproyeksikan diri. Setiap kali ada momen orang mengabadikannya dengan selfie bahkan sekarang momen dicari dan diciptakan.

Fenomena selfie menjadi viral di Indonesia terutama di kalangan Generasi Milenial. Dilansir dari techno.okezone. com Menurut Brand Development Lead Instagram APAC Paul Webster, Instagrammers di Indonesia mayoritas anak muda, terdidik, dan mapan. Rata-rata mereka berusia 18-24 tahun sebanyak 59 persen, usia 25-34 tahun 30 persen, dan yang berusia 34-44 tahun 11 persen. Usia tersebut masuk ke dalam usia generasi milenial dengan rentang tahun lahir 1980-2000 (Ali \& Purwandi, 2016:13) artinya usia saat ini 19-39 tahun. Demam selfie seakan menjadi kegemaran remaja saat ini untuk menunjukkan dirinya pada publik. Perilaku selfie sebenarnya tidak dimaksudkan untuk hal-hal yang negatif, karena hanya sekedar menunjukkan dirinya pada publik melalui sosial media namun dapat berdampak negatif jika merugikan diri sendiri maupun orang lain.

Generasi milenial adalah generasi yang banyak dipengaruhi oleh smartphone internet dan media sosial sehingga mempengaruhi pola pikir, nilai dan perilaku. Generasi milenial disebut sebagai attention seeker. Kondisi ketika mereka merasa menjadi seorang bintang yang menjadi sorotan di media sosial. Mereka merasa semakin banyak komentar atau like yang didapat maka mereka merasa semakin eksis. Keinginan untuk mendapatkan respon baik dan penilaian positif menjadi salah satu alasan tindakan upload foto selfie. Respon orang lain terhadap yang ditampilkan pelaku selfie menjadi ukuran dalam menilai dirinya sehingga konsep diri itu terbentuk. Berkembangnya teknologi kamera depan smartphone mendorong munculnya fenomena selfie dikalangan generasi milenial.

Dikutip dari detiknews.com beberapa kasus akibat korban selfie di Indonesia pada tahun 2016 mayoritas terjadi karena melakukan aksi selfie di tempat-tempatberbahaya sepertidipinggir sungai, di pinggir lintasan kereta api, air terjun bahkan ada yang sampai tergulung ombak saat selfie di pantai. Tidak hanya itu, fenomena selfie di lokasi bencana atau 'wisata selfie' sempat disoroti oleh media asing. Disebutkan oleh salah satu media asing asal Inggris bahwa banyak orang Indonesia mengunjungi lokasi tsunami di Banten agar bisa melakukan selfie dan mendapatkan like di media sosial. Kejadian ini bahkan diberitakan oleh sebuah media internasional asal Inggris, The Guardian, dengan mengangkat judul 
"Disaster gets more likes: Indonesia's tsunami selfie-seekers". Selfie yang pada awalnya dilakukan untuk bersenangsenang namun pada sebagian orang digunakan untuk eksistensi diri yang berujung pada kematian.

\section{Uses and Gratification Theory}

Uses and Gratification Theory adalah perluasan dari teori kebutuhan dan motivasi. Dalam teori kebutuhan dan motivasi, Abraham Maslow menyatakan bahwa orang secara aktif berusaha untuk memenuhi hirarki kebutuhannya. Setelah mereka memperoleh tujuan yang mereka cari pada satu tingkat hirearki, mereka dapat bergerak ke tahap berikutnya. Gambaran mengenai manusia sebagai seseorang yang aktif, berusaha untuk memuaskan kebutuhannya, sesuai dengan ide yang dibawa Katz, Blumler, dan Gurevitch ke dalam kajian mereka mengenai bagaimana manusia mengonsumsi komunikasi massa (West \& Turner, 2007:101). Menurut Katz, Blumler \& Gruvitch (West \& Turner, 2007:102) ada 5 dasar dari teori Uses and Gratification diantaranya: (1) Khalayak aktif dan penggunaan medianya berorientasi pada tujuan; (2) Inisiatif dalam menghubungkan kepuasan kebutuhan pada pilihan media tertentu terdapat pada anggota khalayak; (3) Media berkompetisi dengan sumber lainnya untuk kepuasan kebutuhan; (4) Orang mempunyai cukup kesadaran diri akan penggunaan media mereka, minat, dan motif sehingga dapat memberikan sebuah gambaran yang akurat mengenai kegunaan tersebut kepada para peneliti; (5) Penilaian mengenai nilai isi media hanya dapat dinilai oleh khalayak Dengan memenuhi kebutuhannya pada satu tahap, maka individu tersebut akan mampu melangkah ketahap pemenuhan kebutuhan lainnya. Secara umum kita bisa memahami teori kegunaan dan gratifikasi sebagai teori yang menjelaskan motivasi yang mendorong tiap orang memenuhi kebutuhannya melalui media. Menurut McQuail (2010:424) ada empat motif dalam penggunaan media yaitu Motif Informasi, Motif Integrasi \& Interaksi Sosial, Motif Identitas Diri dan Motif Hiburan.

\section{New Media dan Media Sosial}

Media baru atau new media merupakah sebuah teknologi komunikasi digital yang terkomputerisasi dan terhubung pada jaringan. Salah satu bentuk perkembangan yang merepresentasikan media baru adalah internet. Teknologi konvensional seperti televisi, radio, majalah, surat kabar tidak termasuk kedalam media baru. Internet merupakan sebuah medium yang mampu mengonvergensikan media dari bentuk yang terdahulu yang berfokus pada proses komunikasi.

Media baru merupakan teknologi komunikasi yang memungkinkan terjadinya interaktifitas antara pengguna dan informasi. Kini individu dapat menyebarkan dan mengkonsumsi informasi melalui media. Dewasa ini media baru berkembang pesat ditengah masyarakat yang memiliki karakteristik digital dibandingkan jenis media yang lain.

Kata "media" pada media sosial datang dari "medium" atau wadah yaitu ketika orang dapat saling terhubung dan menjalin interaksi sosial. Media sosial adalah tempat, media perantara, layanan yang memungkinkan individu untuk mengekspresikan diri mereka untuk bertemu dan berbagi dengan rekan lainnya melalui teknologi internet (Kurniali, 2011:170). Berdasarkan penjelasan diatas, dapat disimpulkan bahwa media sosial merupakan salah satu perkembangan dari adanya internet. Melalui media sosial, seseorang dapat saling terhubung satu sama lain yang tergabung dalam media sosial yang sama untuk berbagi informasi 
dan berkomunikasi. Media sosial bersifat lebih interaktif apabila dibandingkan dengan bentuk media tradisional seperti radio, maupun televisi. Melalui media sosial, kita dapat secara langsung berinteraksi dengan orang lain tanpa mengenal ruang dan waktu

\section{Selfie}

Pada Kamus Besar Bahasa Indonesia (KBBI) swafoto (bahasa inggris: selfie) adalah istilah yang digunakan untuk seseorang yang memotret diri sendiri menggunakan kamera atau webcam kemudian diunggah ke media sosial. Istilah selfie kini sudah masuk dalam kamus dan ditempatkan sebagai Oxford English Dictionary's 2013 Word of The Year. Selfie saat ini sudah menjadi lifestyle dalam masyarakat untuk mengabadikan momen kemudian diperlihatkan kepada orang lain. Fenomena selfie tidak terjadi baru-baru ini hanya gaya berfotonya yang lebih dieksplorasi dari masa ke masa. Ada beberapa alasan mengenai kajian foto selfie. Pertama, selfie sebagai wujud dari eksistensi diri pengguna. Kedua, selfie menandakan pengguna melakukan keterbukaan diri (self disclosure) di media sosial. Ketiga, foto merupakan bentuk narsisme digital. Melalui foto diri, pengguna melakukan eksistensi diri untuk menarik kesan pengguna lain dalam pertemanan di media sosial. Foto selfie ini merupakan alat yang untuk berkomunikasi dan dapat memberikan keterangan informasi tentang sesuatu hal kepada orang lain baik secara verbal maupun nonverbal.

\section{Self Disclosure Theory}

Teori Self Disclosure ditemukan oleh Sydney Marshall Jourad (Lahir, 21 Januari 1926, Toronto, Kanada). Teori Self Disclosure kemudian dikembangkan oleh Joseph Luft dan Harry Ingham pada tahun 1955. Menurut Devito (2011:64) keterbukaan diri adalah jenis komunikasi ketika individu mengungkapkan informasi tentang dirinya yang biasanya disembunyikan atau tidak diceritakan kepada orang lain. Istilah keterbukaan diri mengacu pada pengungkapan informasi secara sadar

Devito (Gainau, 2009:5-6) menyebutkan bahwa terdapat lima aspek di dalam self disclosure, yaitu:(1) Amount, yaitu kuantitas dari self disclosure dapat diukur dengan mengetahui frekuensi dengan siapa individu mengungkapkan diri dan durasi atau waktu yang diperlukan untuk mengungkapkan diri individu terhadap orang lain; (2) Valence, valensi merupakan hal yang positif atau negatif dari self disclosure. Individu dapat mengungkapkan diri mengenai hal-hal yang menyenangkan atau tidak menyenangkan tentang dirinya, memuji yang ada dalam dirinya atau menjelekjelekkan dirinya; (3) Accuracy/Honesty, yaitu ketepatan dan kejujuran individu dalam melakukan self disclosure terhadap orang lain; (4) Intention, seluas apa individu mengungkapkan tentang apa yang ingin diungkapkan, seberapa besar kesadaran individu untuk mengontrol informasi-informasi yang akan dikatakan pada orang lain; (5) Intimacy, yaitu bentuk keakraban individu dengan orang lain yang dapat mengungkapkan detail yang paling intim dari hidupnya, hal-hal yang dirasa sebagai impersonal atau hal yang hanya bohong;

\section{Generasi Milenial}

Generasi milenial adalah sekelompok orang yang lahir kisaran tahun 1980 - 2000an. Generasi milenial juga disebut sebagai generasi Y (Badan Pusat Statistik, 2018:15). Maka dari itu millenials adalah generasi muda yang berumur 19 - 39 pada tahun ini. Generasi milenial memiliki ciri-ciri kreatif, informatif, mempunyai passion dan produktif. Dibandingkan generasi sebelumnya, mereka lebih berteman 
baik dengan teknologi. Bukti nyata yang dapat diamati adalah hampir seluruh individu dalam generasi tersebut memilih menggunakan ponsel pintar. Dengan menggunakan perangkat tersebut para millennials dapat menjadi individu yang lebih produktif dan efisien. Dari perangkat tersebut mereka mampu melakukan apapun dari sekadar berkirim pesan singkat, mengakses situs pendidikan, bertransaksi bisnis online, hingga memesan jasa transportasi online. Generasi ini banyak dianggap cepat tanggap untuk menggunakan teknologi komunikasi instan seperti email, SMS, instant messaging dan media sosial seperti facebook dan twitter, dengan kata lain generasi $\mathrm{Y}$ adalah generasi yang tumbuh pada era internet booming.

\section{METODE PENELITIAN}

Metode penelitian adalah suatu cara atau langkah-langkah yang digunakan untuk mencapai tujuan dengan mengumpulkan, menganalisis dan menyajikan data secara sistematis dan objektif untuk menguji suatu hipotesis. Dalam penelitian ini peneliti menggunakan metode penelitian kuantitatif dengan analisis korelasi. Menurut Jonathan Sarwono (2006:37) analisis korelasional digunakan untuk melihat kuat lemahnya antara variabel bebas dan variable terikat sehingga dapat diketahui ada tidaknya hubungan antara dua variabel.

Objek dalam penelitian ini adalah Pengaruh Selfie pada Instagram Terhadap Keterbukaan Diri. Objek penelitian merupakan benda, hal, dan sebagainya yang dijadikan sasaran untuk diteliti (Kamus Besar Bahasa Indonesia, 2019).

Subjek penelitian adalah individu, benda, atau tempat yang dijadikan sumber informasi yang dibutuhkan dalam rangka pengumpulan data penelitian. Istilah lain yang digunakan untuk menyebut subjek penelitian adalah responden. Subjek dalam penelitian ini dipilih secara acak yaitu seseorang baik laki-laki maupun perempuan dengan kriteria berumur 19 sampai 39 tahun dan pernah mengambil potret diri sendiri menggunakan ponsel atau kamera digital dan mengunggahnya ke Instagram

Populasi adalah wilayah generalisasi yang terdiri atas objek atau subjek yang mempunyai kualitas dan karakteristik tertentu yang ditetapkan oleh peneliti untuk dipelajari kemudian ditarik kesimpulannya (Sugiyono, 2014:115). Populasi dalam penelitian ini adalah Generasi Milenial yang berusia 19 sampai 39 tahun.

Sampel adalah sebagian dari populasi yang ingin diteliti yang keberadaannya diharapkan mampu mewakili ciri-ciri dan keberadaan populasi yang sebenarnya yakni sebagian anggota dari populasi yang dipilih dengan menggunakan prosedur tertentu sehingga diharapkan mampumewakilipopulasinya. Peneliti menggunakan teknik Cluster Sampling. Peneliti memilih generasi milenial yang ada di Indonesia kemudian dikelompokkan untuk mendapatkan area yang lebih kecil. Sampel berjumlah 100 responden menggunakan rumus slovin.

\section{Metode Analisis Data Uji Validitas}

Uji validitas dihitung menggunakan SPSS windows melihat masing - masing butir pernyataan, cronbach alpha (dalam Azwar, 2004:158) mengatakan bahwa koefisien yang berkisar antara 0,30 sampai 0,50 telah dapat memberikan kontribusi yang baik terhadap efisiensi lembaga penelitian.

\section{Uji Reliabilitas}

Uji reliabilitas merupakan ukuran suatu kestabilan dan koefisien responden dalam menjawab hal yang berkaitan dengan konstruk - konstruk pertanyaan yang merupakan dimensi suatu variabel dan disusun dalam suatu bentuk kuesioner. 
Variabel tersebut akan dikatakan reliable jika Cronbach's Alpha-nya memiliki nilai lebih besar dari 0,6 (Azwar, 2004:158)

\section{Uji Asumsi Klasik}

Uji asumsi klasik digunakan untuk mengetahui ketepatan data. Menurut Singgih Santoso (2009:342) "sebuah model regresi akan digunakan untuk melakukan peramalan sebuah model yang baik adalah model dengan kesalahan peramalan yang seminimal mungkin. Karena itu, sebuah model sebelum digunakan seharusnya memenuhi beberapa asumsi, yang biasa disebut asumsi klasik." Dalam penelitian ini uji asumsi klasik yang digunakan adalah: Uji Normalitas dan Uji Heterokedastisitas.

\section{Koefisien Determinasi}

Koefisien determinasi

dimaksudkan untuk mengetahui tingkat ketepatan yang paling baik dalam analisa regresi.Untuk mempermudah dalam proses perhitungan dalam penelitian ini, peneliti menggunakan program SPSS versi 20 dengan menggunakan program tersebut hasilnya dapat dilihat pada table model summary berdasarkan nilai dari tabel yang berjudul $R$-square atau melihat angka $\mathrm{R}^{2}$.

\section{Uji Hipotesis}

\section{Pengujian secara parsial (Uji T)}

Uji $\mathrm{T}$ dilakukan dengan cara membandingkan besarnya angka taraf signifikan (Sig) penelitian dengan taraf signifikasi sebesar $\alpha=5 \%$ dengan kriteria pengambilan keputusan sebagai berikut:

1. $H_{0} H_{0}$ diterima, bila $t_{\text {hitung }} t_{\text {hitung }}<$

$t_{\text {tabel }} t_{\text {tabel }}$ pada tingkat signifikan $\alpha=5 \%$ atau 0,05

2. $H_{0} H_{0}$ ditolak, bila $t_{\text {hitung }} t_{\text {hitung }}>$

$t_{\text {tabel }} t_{\text {tabel }}$ pada tingkat signifikan $\alpha=5 \%$ atau 0,05

\section{HASIL PENELITIAN}

Penyajian data diperoleh dari lapangan dengan menggunakan kuesioner. Uji Validitas

Uji validitas adalah suatu ukuran yang menunjukkan tingkat keabsahan suatu alat ukur. Cronbach's Alpha (Azwar, 2004:158) mengatakan bahwa koefisien yang berkisar antara 0,30 sampai 0,50 telah dapat memberikan kontribusi yang baik terhadap efisiensi lembaga penelitian. Pada hasil Uji Validitas Variabel X yaitu Motif Selfie pada Instagram terhadap Variabel Y Keterbukaan Diri Generasi Milenial dinyatakan bahwa dari seluruh item pertanyaan dinyatakan valid karena seluruh nilai kolerasi lebih besar dari $r_{\text {tabel }}$ (>) 0,306.

\section{Uji Reliabilitas}

Reliabilitas berarti keterandalan atau konsistensi. Suatu kuesioner dianggap reliabel jika jawaban seseorang terhadap pernyataan kuesioner konsisten atau stabil dari waktu ke waktu Perhitungan realibilitas dengan menggunakan Cronbach's Alpha dengan kaidah sebagai berikut: (1) Jika nilai alpha $<0,6$, butir pertanyaan dinyatakan tidak reliabel; (2) Jika nilai alpha $\geq 0,6$, butir pertanyaan dinyatakan reliabel. Pada hasil Uji Reliabilitas menunjukan bahwa besarnya nilai Alpha Cronbach dari Variabel X (Motif Selfie) adalah sebesar 0,835, Variabel Y (Keterbukaan Diri) adalah sebesar 0,857 sehingga dapat disimpulkan bahwa setelah dilakukan penelitian kepercayaan terhadap responden-responden menunjukan bahwa penelitian ini realibel karena bernilai $>0,6$.

\section{Analisis Regresi Linear Sederhana}

Menurut Sugiyono (2014:270) regresi linear sederhana didasarkan pada hubungan fungsional ataupun kausal satu variabel independen (X) dengan satu variabel dependen (Y). Persamaan umum regresi linier sederhana adalah:

$$
Y=a+b X
$$

Dimana:

$\mathrm{Y} \quad=$ Variabel Independen

$\mathrm{X} \quad=$ Variabel Dependen 
TABEL 1. Hasil Regresi Linear Sederhana

\begin{tabular}{llllll}
\hline No & Variabel & Koefisien Regresi & T hitung & T tabel & Sig. \\
\hline 1 & Konstanta & 12,009 & 10,317 & 1,2092 & 0,000 \\
2 & Motif Selfie & 1,027 & & & \\
\hline
\end{tabular}

Sumber: Hasil Olah Peneliti (2019)

a $=$ Nilai intercept (konstan) atau harga $\mathrm{Y}$ bila $\mathrm{X}=0$

b = Pengaruh Selfie pada Instagram terhadap Keterbukaan Diri

Berdasarkan TABEL 1 dapat diketahui hasil regresi linear sederhana diperoleh nilai penelitian ini adalah $\mathrm{Y}=$ $12,009+1,027 \mathrm{X}$. Bilangan konstanta (a) sebesar 12,009 dan koefisien variabel motif sebesar 1,027. Sementara itu $\mathrm{t}$ hitung 10,317 lebih besar jika dibandingkan dengan $t$ tabel sebesar 1,2092, dengan tingkat signifikansi 0,000 lebih kecil dari $\alpha=0,05$. Berdasarkan perhitungan statistik yang diperoleh, maka hipotesis untuk penelitian ini yaitu terdapat pengaruh motif selfie terhadap keterbukaan diri generasi milenial.

\section{Koefisien Determinasi $\left(\mathbf{R}^{2}\right)$}

Koefisien determinasi $\left(\mathrm{R}^{2}\right)$ untuk mengukur seberapa jauh kemampuan model dalam menerangkan variasivariabel terikat. Hasil Koefisien Determinasi memperlihatkan bahwa nilai $\mathrm{R}=0,722$ dan koefisien determinasi (Rsquare) adalah sebesar 0,521 hasil dari pengkuadratan koefisien korelasi 0,722 $\mathrm{x} 0,722$. Angka tersebut menunjukkan pengertian bahwa pengaruh variabel motif terhadap keterbukaan diri generasi milenial diperoleh adalah sebesar 52,1\%.

Pada TABEL 2 dapat dianalisis

TABEL 2. Tabulasi Jawaban Responden Variabel X

\begin{tabular}{clccccc}
\hline No & \multicolumn{1}{c}{ Pernyataan } & SS & S & TS & STS & $\begin{array}{c}\text { Total } \\
\text { Skor }\end{array}$ \\
& & & & & & \\
\hline 1 & Dengan memposting foto selfie saya ingin & 25 & 58 & 17 & 1 & 100 \\
& mengungkapkan informasi tentang saya & $25 \%$ & $58 \%$ & $17 \%$ & $1 \%$ & \\
2 & Saya memposting foto selfie untuk berbagi kondisi & 22 & 63 & 14 & 1 & \\
& terkini tentang saya & $22 \%$ & $63 \%$ & $14 \%$ & $1 \%$ & \\
3 & Saya ingin membentuk opini orang lain melalui foto & 21 & 57 & 22 & - & \\
& selfie & $21 \%$ & $57 \%$ & $22 \%$ & & \\
4 & Saya memposting foto selfie karena ingin mendapat & 23 & 49 & 26 & 2 & \\
& apresiasi (like/komentar) & $23 \%$ & $49 \%$ & $26 \%$ & $2 \%$ & \\
5 & Dengan memposting foto saya ingin menunjukkan & 16 & 63 & 21 & - & \\
& status sosial saya & $16 \%$ & $63 \%$ & $21 \%$ & & \\
6 & Saya memposting foto selfie karena mengikuti & 24 & 49 & 23 & 4 & \\
& perkembangan zaman (kekinian) & $24 \%$ & $49 \%$ & $23 \%$ & $4 \%$ & \\
7 & Saya memposting foto selfie untuk berinteraksi & 23 & 58 & 16 & 3 & \\
& dengan orang lain melalui fitur like maupun komentar & $23 \%$ & $58 \%$ & $16 \%$ & $3 \%$ & \\
\multirow{2}{*}{8} & Saya dapat mengisi waktu luang dengan ber-selfie & 23 & 47 & 27 & 3 & \\
& & $23 \%$ & $47 \%$ & $27 \%$ & $3 \%$ & \\
9 & Efek selfie dari fitur Instagram mampu & 22 & 52 & 23 & 3 & \\
& menghilangkan penat dari kesibukan sehari-hari & $22 \%$ & $52 \%$ & $23 \%$ & $3 \%$ & \\
\multirow{2}{*}{10} & Saya memposting foto selfie untuk membuat feed & 22 & 52 & 23 & 3 & \\
& Instagram yang menarik & $22 \%$ & $52 \%$ & $23 \%$ & $3 \%$ & \\
\hline
\end{tabular}

Sumber: Hasil Olah Peneliti (2019) 
dimana pernyataan nomor 1 dan 2 merupakan motif informasi, dapat dilihat bahwa $58 \%$ responden melalui foto selfie memberikan informasi mengenai dirinya kepada followers di Instagram seperti halnya gaya hidup (make up, fashion, dll) yang menandakan responden secara tidak langsung melakukan keterbukaan diri. Selain itu responden juga membagikan informasi berupa kondisi terkini mengenai dirinya.

Pada pernyataan nomor 3 , 4, dan 5 merupakan motif identitas diri, 57\% responden ingin membentuk opini orang lain mengenai dirinya dalam konteks online melalui foto selfie. Dimana melalui foto selfie responden dapat mengetahui bagaimana reaksi pengguna lain melalui like atau komentar karena semakin banyak mendapat like atau komentar secara tidak langsung akan meningkatkan kepercayaan diri sehingga seseorang akan mengulangi selfie kembali. Seseorang juga menggunakan foto selfie untuk menunjukkan status sosial mereka dalam lingkungannya. Hal ini menjadi sebuah kepuasan tersendiri bagi pengguna media Instagram.

Pernyataan nomor 6 dan 7 merupakan motif integrasi dan interaksi sosial, 49\% responden setuju melakukan foto selfie karena mengikuti perkembangan zaman (kekinian) agar selalu terlihat up to date sehingga akan membentuk opini orang bahwa mereka orang yang selalu tau hal terbaru. Oleh karena itu, seseorang dapat dengan mudah berinteraksi dengan orang lain melalui fitur yang sudah disediakan oleh Instagram. Hal ini dapat dilihat dari pernyataan nomor $7,58 \%$ responden setuju bahwa melalui foto yang diposting menjadi jembatan untuk berinteraksi antar sesame pengguna Instagram.

Sementara pada pernyataan nomor 9 dan 10 merupakan motif hiburan dimana responden $47 \%$ berselfie untuk mengisi waktu luang, bersantai, dan menyalurkan emosi. Sesuai dengan teori uses and gratification bahwa seseorang bebas memilih media apa yang akan digunakan, dalam hal ini media Instagram digunakan untuk memenuhi kebutuhannya akan berfoto. Efek selfie yang disediakan oleh Instagram mampu menjadi hiburan bagi seseorang. Selain itu, melalui Instagram seseorang dapat memposting foto selfie saat dirinya berada dalam satu kegiatan atau pada saat jalan-jalan yang kemudian bisa dijadikan feed yang eye catching. Hal tersebut menjadi kepuasan tersendiri bagi seseorang.

Tabulasi jawaban responden atas 15 pernyataan pada variabel Y ditampilkan pada TABEL 3. Pada pernyataan nomor 1,2,3, dan 4 yang merupakan dimensi Amount. Peneliti menarik kesimpulan bahwa $46 \%$ responden mengunggah foto selfie ke Instagram setiap hari baik melalui fitur feed maupun Instastory. Responden tidak setuju jika hanya sesekali mengunggah foto selfie. Dalam sehari $52 \%$ responden posting foto sebanyak 1-3 foto. Jika dilihat dari frekuensinya maka semakin sering seseorang mengunggah foto semakin sering juga keterbukaan diri yang dilakukan kepada pengguna lain. Artinya semakin banyak informasi yang disampaikan seseorang mengenai dirinya.

Pada pernyataan no 5 dan 6 indikator Valence merupakan hal yang positif atau negatif dari self disclosure. Individu dapat mengungkapkan diri mengenai hal-hal yang menyenangkan atau tidak menyenangkan tentang dirinya, memuji yang ada dalam dirinya atau menjelekjelekkan dirinya. Peneliti menarik kesimpulan bahwa $56 \%$ responden tidak segan untuk menunjukkan kelebihan dan kekurangannya melalui foto selfie kepada orang lain, akan tetapi $62 \%$ responden lebih banyak menampilkan sisi positif mengenai dirinya kepada orang lain daripada sisi negatif. Hal tersebut dikarenakan untuk membentuk citra diri dalam konteks online yang baik

Pada pernyataan nomor 8 dan 9 indikator Intention yaitu seluas apa individu mengungkapkan tentang apa yang ingin diungkapkan. Dapat dilihat bahwa $66 \%$ responden menyertakan 
TABEL 3. Tabulasi Jawaban Responden Variabel Y

\begin{tabular}{|c|c|c|c|c|c|c|}
\hline No & Pernyataan & SS & $\mathbf{S}$ & TS & STS & $\begin{array}{l}\text { Total } \\
\text { Skor }\end{array}$ \\
\hline 1 & $\begin{array}{l}\text { Saya memposting foto selfie melalui fitur feed atau } \\
\text { Instastory setiap hari }\end{array}$ & $\begin{array}{c}46 \\
46 \%\end{array}$ & $\begin{array}{c}46 \\
46 \%\end{array}$ & $\begin{array}{c}8 \\
8 \%\end{array}$ & - & 100 \\
\hline 2 & $\begin{array}{l}\text { Melalui fitur feed atau Instastory saya memposting 1-3 } \\
\text { foto dalam sehari }\end{array}$ & $\begin{array}{c}35 \\
35 \%\end{array}$ & $\begin{array}{c}52 \\
52 \%\end{array}$ & $\begin{array}{c}13 \\
13 \%\end{array}$ & - & \\
\hline 3 & $\begin{array}{l}\text { Saya memposting foto melalui fitur feed atau } \\
\text { Instastory biasanya } 3 \text { kali dalam seminggu }\end{array}$ & $\begin{array}{c}15 \\
15 \%\end{array}$ & $\begin{array}{c}37 \\
37 \%\end{array}$ & $\begin{array}{c}41 \\
41 \%\end{array}$ & $\begin{array}{c}7 \\
7 \%\end{array}$ & \\
\hline 4 & $\begin{array}{l}\text { Dalam seminggu saya memposting hanya satu kali } \\
\text { melalui fitur feed atau Instastory }\end{array}$ & $\begin{array}{c}11 \\
11 \%\end{array}$ & $\begin{array}{c}24 \\
24 \%\end{array}$ & $\begin{array}{c}49 \\
49 \%\end{array}$ & $\begin{array}{c}16 \\
16 \%\end{array}$ & \\
\hline 5 & $\begin{array}{l}\text { Melalui foto selfie saya menunjukkan kelebihan dan } \\
\text { kekurangan saya }\end{array}$ & $\begin{array}{c}12 \\
12 \%\end{array}$ & $\begin{array}{c}56 \\
56 \%\end{array}$ & $\begin{array}{c}30 \\
30 \%\end{array}$ & $\begin{array}{c}2 \\
2 \%\end{array}$ & \\
\hline 6 & $\begin{array}{l}\text { Keterbukaan diri saya melalui foto selfie lebih banyak } \\
\text { mencerminkan hal-hal positif daripada negatif }\end{array}$ & $\begin{array}{c}23 \\
23 \%\end{array}$ & $\begin{array}{c}62 \\
62 \%\end{array}$ & $\begin{array}{c}13 \\
13 \%\end{array}$ & $\begin{array}{c}2 \\
2 \%\end{array}$ & \\
\hline 7 & $\begin{array}{l}\text { Saya menambahkan caption pada saat posting foto } \\
\text { selfie }\end{array}$ & $\begin{array}{c}28 \\
28 \%\end{array}$ & $\begin{array}{c}63 \\
63 \%\end{array}$ & $\begin{array}{c}8 \\
8 \%\end{array}$ & $\begin{array}{c}1 \\
1 \%\end{array}$ & \\
\hline 8 & $\begin{array}{l}\text { Saya menambahkan caption yang berkaitan dengan } \\
\text { foto selfie }\end{array}$ & $\begin{array}{c}17 \\
17 \%\end{array}$ & $\begin{array}{c}66 \\
66 \%\end{array}$ & $\begin{array}{c}14 \\
14 \%\end{array}$ & $\begin{array}{c}3 \\
3 \%\end{array}$ & \\
\hline 9 & $\begin{array}{l}\text { Saat memposting foto selfie saya menambahkan } \\
\text { caption berupa quotes }\end{array}$ & $\begin{array}{c}5 \\
5 \%\end{array}$ & $\begin{array}{c}20 \\
20 \%\end{array}$ & $\begin{array}{c}57 \\
57 \%\end{array}$ & $\begin{array}{c}18 \\
18 \%\end{array}$ & \\
\hline 10 & $\begin{array}{l}\text { Foto selfie yang saya posting menunjukkan diri saya } \\
\text { apa adanya }\end{array}$ & $\begin{array}{c}26 \\
26 \%\end{array}$ & $\begin{array}{c}62 \\
62 \%\end{array}$ & $\begin{array}{c}11 \\
11 \%\end{array}$ & $\begin{array}{c}1 \\
1 \%\end{array}$ & \\
\hline 11 & $\begin{array}{l}\text { Saya mengekspresikan diri (senang, sedih, dll) melalui } \\
\text { foto selfie }\end{array}$ & $\begin{array}{c}18 \\
18 \%\end{array}$ & $\begin{array}{c}35 \\
35 \%\end{array}$ & $\begin{array}{c}40 \\
40 \%\end{array}$ & $\begin{array}{c}7 \\
7 \%\end{array}$ & \\
\hline 12 & $\begin{array}{l}\text { Gaya selfie di Instagram mempengaruhi saya dalam } \\
\text { mengunggah foto selfie }\end{array}$ & $\begin{array}{c}19 \\
19 \%\end{array}$ & $\begin{array}{c}55 \\
55 \%\end{array}$ & $\begin{array}{c}24 \\
24 \%\end{array}$ & $\begin{array}{c}2 \\
2 \%\end{array}$ & \\
\hline 13 & $\begin{array}{l}\text { Saya mempunyai gaya selfie sendiri tanpa harus } \\
\text { meniru-niru gaya orang lain }\end{array}$ & $\begin{array}{c}27 \\
27 \%\end{array}$ & $\begin{array}{c}61 \\
61 \%\end{array}$ & $\begin{array}{c}11 \\
11 \%\end{array}$ & $\begin{array}{c}1 \\
1 \%\end{array}$ & \\
\hline 14 & $\begin{array}{l}\text { Saya me-repost foto selfie atau Instastory dari teman } \\
\text { saya }\end{array}$ & $\begin{array}{c}16 \\
16 \%\end{array}$ & $\begin{array}{c}44 \\
44 \%\end{array}$ & $\begin{array}{c}30 \\
30 \%\end{array}$ & $\begin{array}{c}10 \\
10 \%\end{array}$ & \\
\hline 15 & $\begin{array}{l}\text { Saya tidak segan mengambil foto selfie ketika sedang } \\
\text { berkumpul dengan teman-teman saya }\end{array}$ & $\begin{array}{c}30 \\
30 \%\end{array}$ & $\begin{array}{c}56 \\
56 \%\end{array}$ & $\begin{array}{c}14 \\
14 \%\end{array}$ & - & \\
\hline
\end{tabular}

Sumber: Hasil Olah Peneliti (2019)

caption yang berkaitan dengan foto selfie yang diunggah. Artinya, responden melakukan kejujuran dalam mengungkapkan dirinya kepada orang lain. Sedangkan hanya $20 \%$ responden yang menyertakan caption dalam bentuk quotes seperti quotes motivasi, percintaan, dll. Hal ini menandakan bahwa informasi yang disampaikan merupakan bentuk keterbukaan responden.

Pada pernyataan 10,11, 12 dan 13 merupakan indikator Accuracy/Honesty yaitu ketepatan dan kejujuran individu dalam melakukan self disclosure terhadap orang lain. Peneliti menarik kesimpulan bahwa dengan mengunggah foto selfie ke Instagram, seseorang menunjukkan bagaimana dirinya sebenarnya kepada orang lain. Artinya seseorang melakukan kejujuran mengenai informasi tentang dirinya kepada orang lain. $62 \%$ responden setuju bahwa foto selfie untuk menunjukkan dirinya yang sebenarnya namun hanya $35 \%$ yang mengekspresikan dirinya (senang, sedih, marah, dll) melalui foto selfie. Selanjutnya, $61 \%$ responden melakukan kejujuran dengan mempunyai gaya selfie sendiri tanpa harus meniruniru gaya orang lain.

Pada pernyataan 14 dan 15 
merupakan indikator Intimacy yaitu bentuk keakraban individu dengan orang lain. Peneliti menarik kesimpulan bahwa dengan mengambil foto selfie saat berada dengan orang-orang terdekat membuktikan keakraban seseorang dengan orang lain. Artinya, seseorang tidak segan untuk menjadi diri apa adanya dan mengungkapkan hal-hal yang dirasa impersonal. Selain itu, merepost foto selfie menunjukkan bahwa adanya keakraban antar pengguna Instagram.

Menurut Maddox (dalam Kearney, 2018) selfie merupakan pengalaman yang dialami memungkinkan individu untuk mengatakan, "Ini sebenarnya bagaimana saya melihat, dan ini adalah bagaimana seseorang harus memahami saya". Para selfieer membuat identitas mereka secara online dan mengkomunikasikannya kepada orang lain dalam audiensi / komunitas pilihan mereka. Studi ini melihat bagaimana selfie sebagai sarana keterbukaan diri secara online

\section{PEMBAHASAN}

Penelitian ini dilakukan secara online melalui website Google Form. Berdasarkan hasil perhitungan Slovin dengan tingkat kepercayaan 95\%, didapatkan responden sebanyak 100 orang, yakni 23 orang berjenis kelamin laki-laki dan 77 orang berjenis kelamin perempuan.

Tujuan dari penelitian ini adalah untuk mengukur dan menganalisis Motif Selfie Terhadap Keterbukaan Diri Generasi Milenial. Pada hasil Uji Validitas Variabel $\mathrm{X}$ yaitu Motif Selfie pada Instagram terhadap Variabel Y Keterbukaan Diri Generasi Milenial dinyatakan bahwa dari seluruh item pertanyaan dinyatakan valid dan reliabel. Berdasarkan hasil uji asumsi klasik yaitu Uji Heteroskedastisitas nilai signifikansi variabel $\mathrm{X}$ lebih besar dari 0,05 maka dapat disimpulkan bahwa tidak terjadi gejala heteroskedastisitas dalam model regresi. Kemudian pada Uji
Normalitas Kolmogorov Smirnov didapati hasil 0,221 yang mana $>0,1$ sehingga data disimpulkan bahwa model regresi berdistribusi normal.

Berdasarkan hasil analisis data regresi sederhana menghasilkan persamaan $\mathrm{Y}=12.009+1.027 \mathrm{X}$ dimana Interpretasi koefisien, setiap kenaikan satu satuan pengaruh motif selfie Instagram maka keterbukaan diri generasi milenial meningkat sebesar 1.027 satuan. Korelasi yang terjadi memiliki arah positif dan searah, ini terlihat dengan tidak adanya tanda minus (-) di depan angka 1.027. Arah hubungan positif menunjukkan semakin tinggi motif selfie pada Instagram maka semakin tinggi pula keterbukaan diri generasi milenial pada Instagram. Pada tabel T didapati nilai bahwa $t_{\text {hitung }}$ $t_{\text {hitung }}=10.317>t_{\text {tabel }} t_{\text {tabel }}=1,2902$, maka dapat disimpulkan bahwa $H_{0} H_{0}$ ditolak dan $H_{a} H_{a}$ diterima yang berarti terdapat Pengaruh Motif Selfie pada Instagram Terhadap Keterbukaan Diri Generasi Milenial. Dari hasil koefisien determinasi disimpulkan bahwa Pengaruh Motif Selfie pada Terhadap Keterbukaan Diri Generasi Milenial sebesar 52,1\%.

Berdasarkan perhitungan rata-rata, motif selfie yang paling berpengaruh terhadap keterbukaan diri generasi milenial adalah motif informasi dengan Mean sebesar 3,07. Sedangkan untuk indikator motif identitas diri mean sebesar 2,95, motif integrasi\&interaksi sosial sebesar 2,97 dan motif hiburan sebesar 2,92. Hal ini menunjukkan bahwa motif selfie responden pada Instagram adalah motif informasi. Individu mengunggah foto selfie untuk memberikan informasi mengenai dirinya kepada followers di Instagram yang artinya secara sadar mereka melakukan keterbukaan diri. Tujuan penyampaian informasi mengungkapkan pengalaman kehidupan sehari-hari untuk merefleksikan informasi pribadi dikemudian hari.

Berdasarkan hasil perhitungan 
rata-rata pada indikator keterbukaan diri, maka mayoritas responden melakukan keterbukaan diri pada indikator Accuracy/Honesty dengan Mean sebesar 2,95. Sedangkan indikator Amount Mean sebesar 2,87, Valence Mean sebesar 2,92, indikator Intention Mean Sebesar 2,75 dan Intimacy Mean sebesar 2,91. Peneliti menarik kesimpulan bahwa responden melakukan kejujuran atau ketetapan dalam memberikan informasi kepada orang lain. Hal ini menandakan bahwa responden mengunggah foto selfie dengan menampilkan diri apa adanya.

Hasil penelitian ini relevan dengan teori Uses and Gratification yang mengasumsikan bahwa khalayak aktif menggunakan media yang berorientasi pada tujuan dan orang mempunyai cukup kesadaran diri akan penggunaan media mereka, minat, dan motif. Dalam penelitian ini motif penggunaan media yaitu motif akan selfie pada media social Instagram karena melalui media tersebut responden dapat menyampaikan informasi kepada orang lain. Hal ini sesuai dengan asumsi bahwa khalayak aktif dan penggunaan medianya berorientasi pada tujuan dimana tujuan tersebut yaitu melakukan keterbukaan diri. Dalam penelitian ini, responden menggunakaan media sosial Instagram sebagai media yang berfokus pada konten visual dengan teks sebagai pelengkap. Sesuai dengan asumsi dari teori, penilaian mengenai nilai isi media hanya dapat dinilai oleh khalayak. Artinya responden menilai bahwa Instagram merupakan media yang cocok untuk melakukan keterbukaan diri melalui foto selfie.

\section{SIMPULAN}

Setelah melakukan pengujian dan analisa terhadap data penelitian, peneliti membuat kesimpulan yang bertujuan untuk menjawab hipotesis dan pernyataan penelitian yang telah diajukan pada bagian rumusan masalah, maka peneliti menarik kesimpulan bahwa terdapat Pengaruh Motif Selfie pada Instagram Terhadap Keterbukaan Diri Generasi Milenial sebesar 52,1\% sedangkan sebesar $47,9 \%$ dipengaruhi oleh faktor lain yang tidak diteliti dalam penelitian ini. Dari hasil penelitian ini juga diperoleh bahwa indikator motif selfie yang paling berpengaruh adalah motif informasi sedangkan pada indikator keterbukaan diri mayoritas responden melakukan keterbukaan diri pada indikator accuracy/ honesty.

Dikarenakan adanya keterbatasan dan kekurangan dalam penelitian ini, para peneliti selanjutnya diharapkan dapat memperluas populasi dan sampel sehingga hasil yang diperoleh lebih konsisten. Peneliti juga menyarankan untuk menambah variabel diluar variabel yang sudah ada (variabel motif selfie dan keterbukaan diri) dengan menggunakan metode yang lebih mendalam seperti kualitatif atau metode campuran (mix method). Sesuai dengan hasil analisis deskriptif responden, peneliti menyarankan untuk masyarakat umum khususnya pengguna instagram agar lebih bijak dalam menyampaikan informasi melalui foto atau video terkait hal pribadi kepada publik.

\section{DAFTAR PUSTAKA}

Aditya, R. (2015). Pengaruh Media Sosial Instagram Terhadap Minat Fotografi pada Komunitas Fotografi Pekanbaru. Jurnal Online Mahasiswa FISIP, Vol 2, No.2, 1-14.

Alblooshi, A. (2015). Self-Esteem Levels \& Selfies: The Relationship between Self-Esteem Levels and the Number of Selfies People Take and Post, and the Uses and Gratifications of Taking and Posting Selfie. Thesis Middle Tennessee State University .

APJII.com (2019, 05 23). Retrieved from Asosiasi Penyelenggara Jasa Internet Indonesia: https:/apjii.or.id/

Atmoko, B. D. (2012). Instagram Handbook. Jakarta: Mediakita. 
Azwar, S. (2004). Metode Penelitian. Yogyakarta: Pustaka Pelajar.

Detik.com. (2019, 05 20). Retrieved from Detik.com: https://news.detik.com/ berita/d-3204331/7-selfie-berujungmaut-yang-terjadi-di-indonesiasepanjang-2016

Devito, J. A. (2011). Komunikasi Antar Manusia (Edisi Kelima). Tangerang: Kharisma Publishing Group.

Gainau, M. B. (2009). Keterbukaan diri (self disclosure) siswa dalam perspektif budaya dan implikasinya bagi konseling. Jurnal Ilmiah Widya Warta, Vol 33.

Hadi, S. (1991). Analisa Butir untuk Instrument. Yogyakarta: Andi Offset.

https://www.theguardian.com/world/2018/ $\mathrm{dec} / 26 /$ destruction-gets-more-likesindonesias-tsunami-selfie-seekers

Jennifer Kilber, A. B. (2014). Seven Tips for Managing Generation Y. Journal of Management Policy and Practice vol. $15(4), 81$.

Kearney, A. (2018). Uses and Gratification of Posting Selfies on Social Media.

Theses, Rochester Institute of Technology.

Kompas.com. (2019, 05 06). Retrieved from https://tekno.kompas.com/ $\mathrm{read} / 2018 / 06 / 21 / 10280037 /$ juni-2018pengguna-aktif-instagram-tembus-1miliar

Kompas.com. (2019, 05 07). Retrieved from Lifestyle: https://lifestyle.kompas. $\mathrm{com} / \mathrm{read} / 2018 / 12 / 27 / 142313720 /$ selfie-di-lokasi-bencana-beri-simpatiatau-pencarian-eksistensi?page $=$ all

Kuniali, S. (2011). Peran Media Sosial di Internet Pada Penerapan Proses Knowledge Management. Jurnal Bina Nusantara Vol 2, No 1, 167-174.

Lister, M. (2009). New Media: A Critical Introduction. London: Routledge.

Lyons, S. (2004). An exploration of generational values in life and at work. ProQuest Dissertations and Theses, 441.
McQuail, D. (2010). McQuail's Mass Communication Theory 6th Edition. London: Sage Publication.

Neuman, W. L. (2003). Social Research Methods: Qualitative And Quantitative Approaches. Boston: Allyn and Bacon.

Okezone.com. (2019, 05 06). Retrieved from https://techno.okezone.com/ $\mathrm{read} / 2016 / 01 / 14 / 207 / 1288332 /$ pengguna-instagram-di-indonesiaterbanyak-mencapai-89

Rakhmat, J. (2004). Metode Penelitian Komunikasi. Bandung: P.T Remaja Rosdakarya.

Richard West, L. H. (2007). Pengantar Teori Komunikasi. Jakarta: Salemba Humanika.

Santoso, S. (2004). SPSS Versi 11.5 Cetakan Kedua. Jakarta: Gramedia.

Sarwono, J. (2006). Metode Penelitian Kuantitatif dan Kualitatif. Yogyakarta: Graha Ilmu.

Statistik, B. P. (2018). Profil Generasi Milenial. Jakarta: Kementerian Pemberdayaan Perempuan dan Perlindungan Anak.

Sugiyono. (2012). Statistic untuk penelitian. Bandung: Alfabeta.

Sugiyono. (2013). Metode Penelitian Kuantitatif Kualitatif dan $R \& D$. Bandung: Alfabeta.

Sugiyono. (2014). Metode Penelitian Kuantitatif Kualitatif dan $R \& D$. Bandung: Alfabeta.

Valerie Barker, N. S. (2019). This Is Who I Am: The Selfie as a Personal and Social Identity Marker. International Journal of Communication 13, 11431166.

Williamson, P. (2017). Me, My "Selfie" and I: A Survey of Self-disclosure Motivations on Social Media. IAFOR Journal of Cultural Studies, Vol 2-Issue 2.

Zhiying Yue, Z. T. (2015). Me, Myselfie, and I: Individual and Platform Differences in Selfie Taking and Sharing Behaviour. ISBN 978-1-4503-4847-8/17/07. 